\title{
Title: Resolving agency issues in client-contractor relationships to deliver project success
}

\section{Authors:}

David James Bryde

Liverpool Business School, Liverpool John Moores University, Redmonds Building, Brownlow Hill, Liverpool, L3 5UG, UK. Email: D.J.Bryde@ljmu.ac.uk. Tel: +44 (0)151 231 4757. ORCID: 000-0003-1779-9691 (Corresponding author)

Christine Unterhitzenberger

Lancaster University Management School, Bailrigg, Lancaster, LA1 4YX, UK. Email: c.unterhitzenberger@lancaster.ac.ukTel: +441524664521 Twitter: @christine_uhb. LinkedIn: https://uk.linkedin.com/in/unterhitzenberger. ORCID: 000-0001-5815-9127

Roger Joby

Liverpool Business School, Liverpool John Moores University, Redmonds Building, Brownlow Hill, Liverpool, L3 5UG, UK. Email: R.Joby@ljmu.ac.uk.Tel: +44 (0)1189702367 


\begin{abstract}
In our research we seek to explain why some relationships between project client and contractors are managed in such a way that leads to success and others are not. In doing so, we analyze how the relational risk that exists when a client sources a project from an external organization is managed. We view the topic through a lens of agency theory and we use a multiple case study research design, analyzing projects from the construction and clinical research business sectors that had varying degrees of success. We extend knowledge of managing relational risk by developing a framework for resolving agency-related issues to deliver project success. The framework encompasses mechanisms to managing relational risk which we classify in five broad areas: contract, understanding, resources, education and delegation - the CURED framework. These areas reflect both formal and informal mechanisms as described in existing literature.
\end{abstract}

Keywords: client-contractor relationships; project success; case study; agency theory; framework 


\section{Introduction}

There is growing calls in the project management (PM) community to pay attention to understanding the complex dynamics of the social relationships that exist in project teams. This reflects the fact that social and relational aspects of project teams have a high degree of influence on project performance and hence whether a client perceives a project as successful or not. In situations where the client sources a project from a contractor that is external to their organization, the social and relational aspects have an added layer of complexity (Awuzie and McDermott, 2015). The project team comprises individuals that not only differ in their roles and responsibilities but also in their affiliation to different firms. This complexity makes it difficult to achieve the control over outcomes that clients seek (Liu et al., 2017).

The importance of addressing issues of poor project performance is evident from recent statistics on project success and failure. The latest annual "Pulse of the Profession" survey by the Project Management Institute estimates that 9.9\% of every US Dollar spent on projects is wasted due to poor performance (PMI, 2018). One way of addressing the poor performance is through growing "delivery capabilities" (PMI, 2018: 2), where delivery involves the interaction of people working for different organizations when the client has sourced the project from an external contractor. The external contractor in this context can be equalised with the project manager, who is accountable for the delivery of the project outputs, whereas the client is the project owner who is held accountable by the funder and ensures that the business case is realized (Zwikael and Meredith, 2018). In these situations the ability to deliver will be in part based upon the capability of the client and the contractor to create and maintain effective relationships across the organizations. Though such relationships are inherently problematic due to the complexities of multiple organizations coming together and bringing their own ways of working, histories, values, goals and cultures.

Another problem with such relationships is the high levels of uncertainty that can exist as to how each party to the relationship will behave. Such uncertainty is especially problematic if the organizations have not worked together before on a project. These problems are conceptualized as relational risks (Zhang and Qian, 2017), which are key elements of overall project risk, including individual risk. Where individual risk is an uncertain event or condition that, if it occurs, has a positive 
or negative effect on one or more project objectives. The PM literature on methods to manage individual risk is relatively mature, on methods to manage relational risk less so. It is to advancing knowledge in the management of relational risk that our research seeks to make a contribution. This is the first decision we make in terms of delimiting the scope of our study. There are many contributing factors to why PM is effective or not but we focus on how the relationship between client and contractor contributes to project success. Whilst recognizing that success is defined in different ways by different stakeholders at different times (Shenhar et al, 2001) for our study we conceptualize success as delivering the project against time, cost, quality and client satisfaction-related success criteria (Mir and Pinnington, 2014).

With this delimiter established we develop the following aim: to understand how characteristics of the relationship between key PM staff result in success or failure in situations where the client sources a project from a contractor that is external to their organization. To achieve the aim we have two supportive objectives: 1) to analyze, through the lens of agency theory, the characteristics of relationship management in such situations 2) to propose a framework for relationship management that maximizes its potential usefulness to PM.

A second scope delimiter is our use of agency theory. As a lens through which to analyze the problem of such relationships, agency theory explains the behaviors between principals and agents. This applies to situations where there is a client in an owner organization, who is the principal and a contractor in a project organization, who is the agent (Turner and Müller, 2004); which is the case where the client sources a project from a contractor that is external to their organization. Whilst we recognize there are other theoretical lenses that could be used, such as Transactional Cost Economics, these are outside the scope of our study. By developing a framework we intend to highlight the mechanisms to manage the relationship used by clients and contractors during a project, levels of project success and failure and agency-related causes; as well as the relationships between these three elements. 


\section{Literature review}

\subsection{Agency theory}

The decision by a client to source work from a contractor that is external to the client organization takes place in many project-based industry sectors as a matter of course. Such projects can be complex and problematic to manage due to the abundant number of boundaries that need overcoming between the different organizations i.e. different organizational cultures, objectives or individual roles. This also creates challenges of managing the client for the contractor and vice versa.

One challenge relates to overcoming agency-related problems that arise in situations that involve clients and contractors from different companies. Here a principal-agent relationship exists where the principal (client), typically through a formal contract, engages the agent (contractor) to perform a service on their behalf. In doing so, the principal delegates decision-making authority to the agent (Jensen and Meckling, 1976). One reason for the presence of dysfunctionality between client and contractor can be the presence of problems associated with the principal/agent relationship that exists between the two parties.

Agency theory explains how relationships operate in numerous principal/agent contexts and how to mitigate or manage agency problems. Recent prior research utilizing agency theory in this way has encompassed diverse operational contexts. Examples include franchising set-ups (Zhang et al., 2015), service triads (Van der Valk and Iwaarden, 2011), internal organisational service providers (Bhattacharya et al., 2013), information technology contracts and implementation (Chen and Anandhi, 2009; Gopalakrishnan, 2017; Taylor, 2007), hotel management (Lamminmaki, 2011), contracting food and drug manufacture (Handley and Gray, 2013) and transportation (Logan, 2000). Given this prior work, agency theory is a useful lens through which to glean insights relating to the client/contractor relationship.

\subsection{Agency-related issues}

Agency-related issues arise due to the phenomena of adverse selection and moral hazard. The adverse selection problem relates to the fact that there is information asymmetry between the principal and the agent (Akerlof, 1970, Eisenhardt, 1989). There is a level of uncertainty arising from this 
information asymmetry before a client awards a contract to a contractor that jeopardizes efforts made to establish a functional working relationship between the two parties (Dahlstrom and Ingram, 2003). Information asymmetry can fuel mistrust for the client and generally lead to detrimental behaviors (McCarthy et al., 2013). Moral hazard problems refer to situations where the principal has difficulties directing the agents' actions because the actions are unobservable or cannot form part of the contract (Byford, 2017). Again, information asymmetry is present. This enables the contractor to operate in an opportunistic way, post-contract award, if they so wish. The contractor has his or her own goals, such as making a profit from undertaking the project and these goals may not align with what the client is expecting the contractor to deliver. Where goals are in conflict the contractor will often act in the interest of their own company at the expense of the project and the client and might act on information that they have not shared with the client in a way that does not benefit the client (Eriksson et al., 2016). With levels of information asymmetry high, the contractor knows more than the client about project issues, progress etc. The client can feel that contractor's decisions are not in their best interest and without the means to refute this assertion, a destructive cycle of increasing levels of mistrust, concealment of information and gaming by both parties can form (Turner and Müller, 2004, Abrahamson and Park, 1994, Obloj and Zemsky, 2014).

Another area where agency problems arise is where uncertainty exists and discussions in the literature highlight that allocating benefits and risks between the two parties is necessary in such situations (Melese, et al., 2017). How this is done can be viewed from two perspectives. Firstly from the value sharing perspective, which suggests agents cooperate in order to gain value and secondly from the risk sharing perspective, which uses the concept of risk sharing to explain why agents cooperate. The construction of the contract reflects these perspectives - see discussion above on the type of contracts used to address agency problems in collaborative project environments. Uncertainty creates a relational risk, which results from behavior uncertainty of other parties to the project (Zhang and Qian, 2017). A high perception of relational risk increases the inclination of a contractor to act opportunistically. To mitigate for this clients must continually focus on dealing with relational risks during a project. 
So in project environments, agency-related issues related to adverse selection and moral hazard as well as uncertainty span the whole of the project life cycle, encompassing the phases prior to the award of the contract and the phases post-contract when the contractor is tasked with delivering the project. Theorists suggest that well-constructed contracts help avoid potential agency-related problems between client and contractor (Farrell, 2003). Ideally, the parties agree a contract to enable the agent to maximise their self-interests, whilst at the same time they are working to deliver the project in such a way that the client maximises their benefit (Lui et al., 2016).

One strand of early agency-theory literature considers which type of contract is best suited to different principal/agent contexts (Melnyk, et al., 2004). Contracts are distinguished between outcomebased and behavior-based (Florical and Lampel, 1998), with fixed-priced contracts being outcomebased and fee-for-service ones being behavior-based. Agency theory explains that the contractor will act in the client's best interest when outcome-based contracts are used or where the client has enough information to verify behavior - if behavior-based types of contracts are used. There are a number of factors influencing the choice between outcome and behavior-based contracts. These include the character of information systems used, the level of outcome uncertainty, the attitudes towards risk aversion, the level goal conflict - discussed above, the extent of task programmability, the level of outcome measurability and the length of time that the client and contractor have had a relationship (Eisenhardt, 1989). The last of these factors is a rationale for developing long-term strategic partnerships, with incentivizing contracts that reward certain desirable behaviors by the contractor, such as sharing knowledge or being innovative. When such long-term relationships exist, according to agency theory, the client and the contractor will have learnt about each other and the degree of information available to the client on the contractor's behaviors will be greater than if they had a shorterterm relationship. In such situations, behavior-based contracts become more attractive to clients.

Apart from the type of contract it is also suggested to consider the contractual completeness. Contractual completeness is the extent to which the two parties have a contract in place that is fit for purpose (Handley and Benton Jr., 2009). If present, the contract enables effective coordination of 
resources and allocation of risk. It also addresses potential inter-organizational risks relating to the functioning of the relationship between the client and the contractor.

\subsection{Mechanisms to address agency issues}

The contract is an example of a formal and explicitly designed control mechanism used to solve agency problems. Such mechanisms attempt to control both project outputs and behaviors. In addition to formal mechanisms, there are informal and implicit control mechanisms (Langfield-Smith and Smith, 2003). Examples of formal mechanisms, besides the contract, are PM policies, procedures, reporting structures, staffing and training (Badenfelt, 2010). Informal mechanisms seek to reduce goal incongruence by fostering a culture of shared values between client and contractor. Examples are fostering a partnership spirit through the cross-cultural exchange of ideas and recognizing performance by the contractor that is indicative of such a spirit, such as how the contractor responds to client requests for changes to the project. Here the client has a crucial role to play in maintaining the right balance between promoting desirable behaviors and eliminating, through the reinforcement of formal controls, of behavior deemed undesirable.

To summarize, the literature has paid some attention to mechanisms to solve agency problems in projects. This literature has traditionally focused on the formal PM mechanisms, including the choice of contract, and, to a lesser extent, the PM policies and procedures put in place to ensure communication takes place to report project progress. Work that is more recent has identified that, in addition to these formal mechanisms, more informal and implicit control mechanisms, focusing on the actions of the clients and contractors at the micro-level are important in dealing with agency issues. This strand of research is still in its infancy, being either conceptual in nature or based on a small number of surveybased studies of a single industry (see, for example, Zhang and Qian, 2017, which studied construction projects in China) or single case studies (see, Badenfelt 2010), which analyzed a large laboratory construction project over a three year period). Promoting this line of enquiry, a call is made for further research into how agency problems are resolved in client/contractor collaborative projects that considers not only the formal mechanisms put in place but also the social roles and interactions between the client and main contractors participating in delivering a project (Badenfelt, 2010). We respond to 
this call by focusing on understanding how clients and contractors interact at the micro-level of the project to ensure the relationship between the two parties functions effectively and, hence, preempts or resolves agency issues that arise. In doing so we seek to understand the importance of the informal mechanisms as well as the formal ones.

\section{Research method}

\subsection{Research design}

To explore agency-related issues in situations where the client sources a project from a contractor that is external to their organization we adopted a multi-case qualitative research design (Yin, 2013). Whilst such an approach offers only limited generalizability, the collection of rich data from multi-cases provides an opportunity to contribute significantly to knowledge and theory building (Barratt and Barratt, 2011). Case based research is also particularly appropriate in situations where there is little previous literature or prior empirical evidence about a phenomenon (Eisenhardt, 1989a) - as with the topic of relationship management to projects where client and contractor reside in different organization. Therefore, using case studies offers the prospect of developing a deep understanding of the impact of aspects of relationship management on the performance of such projects. Having decided upon a case study approach guidance provided by Stuart et al. (2002) on undertaking effective case research in operations management informed the specific research method adopted for the study. The unit of analysis was the project.

\subsection{Case study selection criteria}

In terms of delimiting the scope of our research, we took two projects from the construction industry and two from health care, specifically the undertaking of clinical research as the four cases for analysis. We chose these two industries as they enabled some generalizing of the findings beyond one sector. They are both industries that routinely undertake project work and hence have maturity in the use of PM (Grant and Pennypacker, 2006). Construction and clinical research are appropriate to compare as the projects typically undertaken in both sectors have relatively clear goals and well-defined methods 
to achieve the goals - so they are the same type of project from a PM perspective (Turner \& Cochrane, 1993). Hence whilst providing very different products and services, they have much in common in respect of the operational demands on the PM function. The construction and clinical research industries also typically involve the client sourcing project work from a contractor in another company - as was the case for each of the four projects selected for analysis - so a principal/agent relationship was present for each. Two of the projects were classed as successful - one each from construction and from clinical research - and the other two, one from each industry, unsuccessful. A multi-dimensional construct defined success, with the dimensions being meeting time, cost and quality objectives and satisfying the client (Chipulu, et al., 2014, Mir and Pinnington, 2014). This reflects the focus of our study being on the management of the relationship between client and contractor during the project execution phase, where the attention is primarily operational and on getting the job done (Shenhar $e t$ al, 2001).

\subsection{Data collection}

We used multiple sources of evidence, which enables triangulation and hence enhances reliability (Barratt, et al. 2011). Table 1 contains details of the methods for each of the four cases. As shown in the table, we collected data to frame the cases and then towards the end of each project (case). In the framing phase, we undertook an initial sense-making and orientating data collection in order to achieve a full picture of the wider environment in which each project was undertaken. We held meetings with client representatives responsible for the delivery of projects in their organization - at least one per case as shown in table 1 - to gain a sound understanding of the types of projects undertaken their performance and the project appraisal and selection activities undertaken pre-contract award. We took contemporaneous notes during the meetings. We deepened our knowledge of how each client organization selected contractors and subsequently managed the relationship between them by analyzing internal documents and, for the two cases in which there were publicly listed clients, documents in the public domain. 


\begin{tabular}{|c|c|}
\hline CASES & DATA COLLECION METHODS \\
\hline $\begin{array}{c}\text { Case } A-\text { construction } \\
\text { project } 1 \text { - airport } \\
\text { terminal }\end{array}$ & $\begin{array}{c}\text { Framing phase } \\
\text { Information gathering on client and their projects through meetings with } \\
\text { Head of Program Controls (Client) (x2) and previous Head of Planning } \\
\text { (client), document review of project management methodology and } \\
\text { company/project information in the public domain } \\
\text { Project phase } \\
\text { Interviews with 1) client program manager, 2) contractor program manager } \\
\text { and 3) project managers (client) x 2, review of internal project control } \\
\text { documents and review of project performance data in the public domain }\end{array}$ \\
\hline $\begin{array}{c}\text { Case } B \text { - construction } \\
\text { project } 2 \text { - new water } \\
\text { reservoir }\end{array}$ & $\begin{array}{l}\text { Framing phase } \\
\text { Information gathering on client and their projects through meetings with } \\
\text { Head of Project Delivery System (x2) and Project Administration Officer, } \\
\text { document review of contractor selection process, project management } \\
\text { methodology and company/project information in the public domain } \\
\text { Project phase } \\
\text { Interviews with 1) client project manager, 2) client contracts manager and 3) } \\
\text { contractor project manager, review of internal project performance } \\
\text { documents and review of project performance data in the public domain }\end{array}$ \\
\hline $\begin{array}{c}\text { Case } \mathrm{C} \text { - clinical trial } \\
\text { project } 1 \text { - } \\
\text { investigational } \\
\text { product for the } \\
\text { treatment of lung } \\
\text { cancer }\end{array}$ & $\begin{array}{c}\text { Framing phase } \\
\text { Information gathering on client and their projects through meeting with } \\
\text { Clinical Outsourcing Director (client) and document review of contractor } \\
\text { selection process, specific contracts, preferred supplier relationship, project } \\
\text { management methodology } \\
\text { Project phase } \\
\text { Interviews with 1) client project manager and 2) contractor project manager } \\
\text { and 3) project administrator and review of internal project scheduling and } \\
\text { control documents }\end{array}$ \\
\hline $\begin{array}{c}\text { Case } \mathrm{D}-\text { clinical trial } \\
\text { project } 2- \\
\text { investigational } \\
\text { product for the } \\
\text { treatment of } \\
\text { haemophilia }\end{array}$ & $\begin{array}{c}\text { Framing phase } \\
\text { Information gathering on client and their projects through meeting with } \\
\text { Head of Clinical Operations (client) and document review of contractor } \\
\text { selection process, contracts, project management methodology } \\
\text { Project phase } \\
\text { Interviews with 1) client program manager 2) client project manager 3) } \\
\text { client project administrator 4) contractor project manager 5) senior } \\
\text { contracts manager 6) executive director and review of internal project } \\
\text { monitoring and control documents }\end{array}$ \\
\hline
\end{tabular}

Table 1 - Data collection methods

A key part of the framing phase was to identify four projects, one per organization, that met the selection criteria - described in section 3.2 above - and to agree with the client access to collect data on the selected project. We selected four projects that were coming towards the end, so the project team was still in place for interview purposes and issues relating to the project were fresh in people's minds. Being close to planned or actual completion dates an assessment of success was possible i.e. it was clear that the contractor was meeting the objectives set and that client satisfaction was high, or not, as the case might be. In this phase, we also collected data from the client on the contractual relationship with the contractor. 
The next phase of data collection involved semi-structured interviews with key staff involved in the PM from both client and contractor perspectives and oversight of internal documents relating to project performance held internally within the client organization or in the public domain. In total 16 interviews were undertaken, with 9 from the client side and 7 from the contractor side. Four for Case A (3 [client], 1 [contractor]), three for Case B $(2,1)$, three for Case C $(1,2)$ and six for Case D $(3,3)$. We structured the interviews around the following 5 broad areas, going into more depth in each area where appropriate to gain insight into the agency-related problems encountered and how they were overcome, if they were. 1) The person's project role, involvement and key client/contractor relationships. 2) Their appraisal of the success of the PM, including satisfaction with their own and others performance. 3) The reasons for their appraisals. 4) The PM structures, processes and procedures used, including the methods for communicating between client and contractor. 5) How these structures, processes, procedures and methods affected project success and the client/contractor relationship. The longest interview lasted 2.5 hours and the shortest interview 1.5 hours. The average interview time was 1.75 hours. We recorded and transcribed each interview.

The review of internal and external documents served the purpose of triangulation with the data obtained in the interviews, in relation to the actual performance of the projects. For each case we had sight of internal project control documents which encompassed some, but not all aspects of performance as well as scheduling and monitoring documents. For Case A and B we also used data from the public domain which provided additional information about project performance.

It is worth noting at this point two challenges related to the data collection. Firstly, the access to project documentation was sometimes limited due to the issue of financial disclosure of commercially sensitive information, especially in relation to profits and costs. In the absence of access to such documentation there was sometimes a reliance on the data collected via the interviews being an accurate representation of the performance of the project. Secondly, whilst in general the clients and contractors were willing to be open and honest in sharing their opinions and experiences - which was helped by the research following strict ethical guidelines guaranteeing anonymity and respecting the need for confidentiality - we were aware that it could be the case that interviewees might be more willing to share their experiences in the 
case of the projects that were perceived to be relatively more successful than those perceived to be problematic. Being mindful of these two challenges we constantly reflected on the context in which the data were collected and the need, where possible, to verify any findings from additional data sources - which included, if possible, verification from both client, contractor(s) or, in respect of Case A -construction project 1- the Managing Service Provider (MSP). In this respect Case A presented a specific challenge in that direct access to the contractors in order to conduct interviews was not possible and here the data collected from the MSP acted as a proxy for experiences of the Contractor(s) - see Case A, Organization Structure in the Appendix 1 for further details of the MSPs role. In this case we were also able to validate findings from the interview through the analysis of documents in the public domain.

\subsection{Data analysis}

We analyzed the interview data in two stages. Firstly, we used thematic analysis, using the lens of agency theory, to identify and explore issues present in each project relating to the client-contractor relationships and their effect on performance. A thematic qualitative approach is a widely used and reliable method of analysis (Braun and Clarke, 2006; Maaninen-Olsson and Müllern 2009). It is also highly flexible, so well suited to analyzing the data collected through the semi-structured interviews. To enhance inter-coder reliability two members of the research team independently undertook the analysis and then compared results. The thematic analysis shed light on the reasons for the different levels of project performance and it allowed us to undertake a cross case analysis. For the cross case analysis we compared commonalities and differences between the four cases in order to identify patterns.

Furthermore, a content analysis of the interview transcripts was undertaken using a phrase as the unit of analysis. From the review of the prior literature on agency theory, we identified six variables to frame this analysis: goal conflict, opportunistic behavior, information asymmetry, trust, information to verify contractor performance and concealment of negative outcomes. A count of phrases appertaining to each variable was done. For example, if a phrase identified a degree of goal conflict between the client and the contractor then it was marked as negative statement - indicating a high degree of goal conflict. Conversely, a phrase identifying an absence of such conflict was marked as a 
positive statement, meaning low goal conflict. A count of the total of negative and positive statements was made and from that percentages for each were calculated. Where there was a clear distinction in terms of the percentage of positive $\mathrm{v}$ negative statements, then a high or low classification was made. If there was no such distinction it was marked as neutral. We also used the other sources of data i.e. project documents to verify the evaluation of the data. Typically, an analysis of a transcript for a given variable revealed either a predominance of positive or negative statements, with few resulting in a neutral classification. For example for one of the projects (Case D) there were 28 phrases in the interview transcripts relating to goal conflict that were negative and only one positive statement, hence the case was classified as having high goal conflict. This compares with Case A, which had 13 positive statements and only 4 negative. Therefore, this resulted in a classification for the project of having low goal conflict.

\subsection{The case studies}

Below we describe the four case study projects used for this research. Appendix 1 provides supplementary information regarding project scope, organization structure, project structures and processes, and the selection criteria for inclusion of the projects.

- Case A - construction project 1 - airport terminal: the client has over 70 years of experience managing a major international airport and of undertaking projects to upgrade and expand the physical facilities for airlines and passengers that use the airport. Its annual revenue is $\$ 3.8$ billion and it employs approximately 5,000 people. The contractor is a large sized consultancy company serving multiple industries with a turnover of approximately $\$ 1.9$ billion and a workforce of 19,000 worldwide. Whilst going through a series of mergers over time the company has been in existence in some form over 100 years. They provide strategic built asset advisory and project delivery services to clients, as to Case A. The contractor had previously collaborated with the client on projects, being one of four suppliers on the client's procurement framework. The project involved the construction of a new purpose built airport terminal with a budget of approximately $\$ 1.2$ billion. The project was part of a long-term $\$ 3.2$ billion capital programme to upgrade the airport facilities. Against the multi- 
dimensional PM criteria described earlier in this section of the paper, the project was judged as successful and the client was very satisfied with the outcome.

- Case B - construction project 2 - new water reservoir: the client is a private water and wastewater company with an annual revenue of $\$ 2.2$ billion and employing 5,000 people. They are well experienced in undertaking large-scale projects, with rolling five-year capital programs worth approximately $\$ 5.5$ billion. The contractor is a small-sized civil engineering company, established for 25 years and based locally to the site of the project. When bidding for work they emphasize their experience in dealing with environmental issues, meeting health and safety targets, as well as the expected ability to deliver to time, cost and specification. The contractor had undertaken work for the client in the past, being on its list of approved suppliers. The project involved construction work on two reservoirs. The discontinuation of one reservoir, the establishment of a new one, with associated works, such as water draining, landscaping and river reinstatement. The budget was approximately $\$ 2.4$ million. We judged the project as unsuccessful, with the client unhappy with the performance against numerous key performance indicators (KPIs).

- Case C - clinical trial project 1 - treatment of lung cancer: the client is a large multi-national pharmaceutical company (pharma), employing over 10,000 people worldwide and with an annual revenue of approximately $\$ 5.3$ billion. They undertake drug development for treatment of cancer and the central nervous system. They outsource the clinical research phases of the drug development to contractors who are specialist clinical research organisations (CROs) and who manage the various phases of clinical trials as projects. The CRO are part of a large global organisation with approximately 55,000 employees in more than 100 countries and annual revenues of approximately $\$ 10$ billion. The pharma and the CRO had a four-year history of collaboration on such projects. The project was a phase III clinical trial, which is the final stage before marketing a drug, involved testing a new drug on 1,000+ patients across multiple countries. The stakeholders to such projects are the pharma and CRO project staff, clinical specialists in the two companies, clinicians at hospitals participating in the trials, patients, central laboratories, regulators, ethics committees and drug 
manufacturer and suppliers. Our judgement was this project was successful. The client was very satisfied with all aspects of the project.

- Case D - clinical trial project 2 - treatment of haemophilia: the client is a small-sized biotechnology company with sites in the US and UK, approximately 3,000 employees and annual revenue of approximately $\$ 400$ million. They undertake clinical trials of blood related products, and as for Case $\mathrm{C}$, they outsource all stages of the trial to a CRO to project manage. They are well experienced in undertaking such projects. The CRO is medium sized with approximately 900 employees and an annual revenue of approximately $\$ 26$ million. The two companies had no history of working together prior to this project. The project was a phase III clinical trial of a drug for the treatment of a rare form of haemophilia involving 20-30 patients across countries, with the same PM structure and stakeholders as in Case C. This was the second unsuccessful project. Its project failure resulted in the client cancelling the contract with the contractor part way through the execution phase.

\section{Findings}

\subsection{Agency issues in the four cases}

Analyzing the four cases through the lens of agency theory, possible reasons as to why two of the projects were successful, whilst two were not, emerge. The case with the highest level of goal conflict was Case D - clinical trial 2. A high level of goal conflict was evident with references made to being involved on the project as a "battle". The root cause of this conflict was a failure to reconcile the different ways in which value is recognized and rewarded. Both parties to a project are seeking to maximize value from undertaking the project. For a client value typically comes at the end of the project when they can realize the intended benefit. For a clinical trial, this benefit is in a potential new drug, so the value is unlocked when the contractor delivers a final report to the client that contains data on how the drug performed. The cost of producing this final report is not high - an example might be $\$ 50,000$ - but the future value to the client might be millions of dollars. The value of the project to the contractor though is typically in the early stages of execution where a high level of activities take place in setting up the clinical trial. Activities that the contractor will seek financial reward for undertaking. Therefore, we see the value curves for client and contractor over the project execution phase reversed. 
From low to high for client and from high to low for contractor. In the words of the senior contracts manager for the contractor in Case D "this difference [....] sets the scene for the battleground."

A perception from both client and contractor that they were involved in a battle over misaligned value curves resulted in unresolved goal conflict. Therefore, from the very start of Case D the roots for agency problems to take root and grow were in place. As the project commenced the actions of both parties exacerbated the problems. A quote from the client program manager encapsulates the poor state of the relationship between the two parties.

"They [the contractor] keep describing the project manager as a facilitator, they keep using the word facilitation in there. Well, I don't think that's correct and I have not actually raised it with them because it's been in, it was said in one context, and apparently it was mentioned at another meeting but in a slightly different context where facilitation may have been the correct description of the activity. But, and maybe, maybe that's where we go wrong, that they think that a project manager is a facilitator and not a manager." (Client program manager)

On a superficial level, the program manager's comments reveal a state of affairs between client and contractor in which they cannot even agree on what word to use to describe the project manager's main function. On a deeper level, though, they hint at a fundamental difference of opinion as to the role of the contractor in the project, which the client felt unable or unwilling to discuss with the contractor. Things were going wrong, as the client program manager admitted, but by not discussing them with the contractor, they have no chance to be resolved.

The other three cases did not show such high levels of goal conflict, with no evidence that they were engaged in an adversarial relationship that failed to appreciate when each party to the relationship got value from the project, akin to a military battle where one side can only win by the other side losing. For example, the client program manager for Case A - construction project 1 - explained how "we could see that work was being progressed, the value was being added and everyone was in a better frame of mind moving forwards." As with the clinical trial in Case D, the benefits from the construction project would be realized when the facility was completed and made operational, yet the client recognized that the activities undertaken early in the execution phase are a necessary precursor to such benefit realization and hence of high value. From the contractor perspective, this client attribute was 
highly beneficial as "having the cohesion of a client that understood and interrogated very well the whole concept of the value" (contractor program manager) contributed to the success of the PM.

In contrast to the example of Case $\mathrm{D}$ described above, Case $\mathrm{C}$ showed an absence of agencyrelated problems, which would affect project performance adversely. The client project manager stated that the project went "well, there weren't any major issues. It went better than expected really". It exhibited high levels of trust, as evidenced in a further comment of the client project manager that they trusted the contractor not to take unfair advantage of opportunities.

"I think it has worked very well with them - yes you don't feel that they would take any opportunities, that they are working very professionally, I mean we are all working for the same goal." (Client project manager)

Building up trust was an activity to which both the individual client/contractor project managers paid much attention. This build up took place over time and involved incremental steps whereby both parties delivered on promises made. The contractor project manager believed the trust given to the contractor to manage the project in the way they felt best suited the project was a crucial factor in the success of the project. "I think one of the key things [to success] was also again the trust that the sponsor [client] gave us to manage the study like we did" (contractor project manager). This trust build up seemed to negate for the fact that there was not a high "Level of information to verify Contractor performance" against. Things went well on the project. There was no goal conflict. So there was no strong desire on the client's part to know in detail how the contractor was performing against certain metrics. It is appropriate to ask what might have happened if the project had encountered major issues. Would the absence of a highly formal PM execution process been a major weakness in the approach to relationship management adopted by the Client?

Unlike Case C, Case B saw trust that had built up over time lost through situations where the client believed the contractor had failed to communicate crucial information in a timely fashion. This could be something easily communicated to the client by the contractor. For example, the client project manager described how "I was told Monday morning that the guy had left Friday and he was quite a senior person in the company". For the client project manager, such actions by the contractor "doesn't 
help with the trust and building up trust." Another example was an accident on site where the contractor did not immediately inform the client and hence the client was not able to carry out their statutory duty and report the incident to the Health \& Safety Executive. Therefore, there was concealment of negative outcomes which, accompanied by opportunistic behavior meant that trust was lost.

Indeed, as with Case D, agency problems both multiplied and amplified in Case B as different factors influenced other factors. Ultimately, this resulted in the client's low level of satisfaction caused by a vicious cycle of inter-dependent factors affecting each other in increasingly negative ways. The client's PM function was under pressure to meet the demands of their own key stakeholders, both internal and external. They did this by focusing on having their own KPIs met. Part of this was having confidence that the PM processes were being carried out as defined i.e. on doing things right. To get this confidence the client, in their opinion, needed detailed information from the contractor relating to their activities, as well as their performance. The fact that they struggled to get this level of detail and so, as they felt, could not verify contractor performance to the extent that they would have liked led to frustration on all sides. The client never saw themselves adequately in control of the project; whilst the contractor perceived the client to be more interested in being seen to be doing things right, than being interested in doing the right things.

\subsection{Cross-case analysis of agency issues}

Table 2 summarizes the key differences between the successful and unsuccessful projects. The profiles of Case C and Case D illustrate how agency-related causes classically explain either success or failure. In doing so they confirm the validity of agency theory as a useful lens through which to view the topic. With the exception of the level of information to verify contractor performance, which was classed as neutral in Case $\mathrm{C}$, all agency-related causes were either present or absent as per agency theory: degree of goal conflict, degree of opportunistic behavior, degree of information asymmetry, level of trust and level of concealment of negative outcomes. The profiles of Case A and Case B show some variations from the theory and point to nuances of causes. For Case A, there was success despite neutral ratings for opportunistic behavior, trust, and concealment of negative outcomes. Offsetting these were the theoretically desirable characteristics of low goal conflict, low information asymmetry and high level 
of information to verify contractor performance. For Case B, which was unsuccessful, there was also low goal conflict. Unlike Case A though, information asymmetry was not low and level of information to verify contractor performance was not high. These differences hint at the importance of the interplay between individual agency-related causes and levels of success.

\begin{tabular}{|c|c|c|c|c|c|c|c|}
\hline \multirow{2}{*}{ CASE } & \multirow{2}{*}{$\begin{array}{l}\text { PROJECT } \\
\text { SUCCESS }\end{array}$} & \multicolumn{6}{|c|}{ CAUSES OF SUCCESS/FAILURE - AGENCY-RELATED } \\
\hline & & $\begin{array}{l}\text { Degree } \\
\text { of Goal } \\
\text { Conflict }\end{array}$ & $\begin{array}{c}\text { Degree of } \\
\text { Opportunistic } \\
\text { Behavior }\end{array}$ & $\begin{array}{l}\text { Degree of } \\
\text { Information } \\
\text { Asymmetry }\end{array}$ & $\begin{array}{c}\text { Level of } \\
\text { Trust }\end{array}$ & $\begin{array}{c}\text { Level of } \\
\text { information } \\
\text { to verify } \\
\text { Contractor } \\
\text { performance }\end{array}$ & $\begin{array}{c}\text { Level of } \\
\text { concealment } \\
\text { of negative } \\
\text { outcomes }\end{array}$ \\
\hline $\begin{array}{l}\text { CASE C Clinical trial } \\
\text { project } 1- \\
\text { investigational product } \\
\text { for the treatment of } \\
\text { lung cancer }\end{array}$ & \multirow[t]{2}{*}{ HIGH } & LOW & LOW & LOW & HIGH & NEUTRAL & LOW \\
\hline $\begin{array}{l}\text { CASE A Construction } \\
\text { project } 1 \text {-airport } \\
\text { terminal }\end{array}$ & & LOW & NEUTRAL & LOW & NEUTRAL & HIGH & NEUTRAL \\
\hline $\begin{array}{l}\text { CASE D clinical trial } \\
\text { project } 2- \\
\text { investigational product } \\
\text { for the treatment of } \\
\text { haemophilia }\end{array}$ & \multirow[t]{2}{*}{ LOW } & HIGH & HIGH & HIGH & LOW & HIGH & HIGH \\
\hline $\begin{array}{l}\text { CASE B construction } \\
\text { project } 2 \text { - new water } \\
\text { reservoir }\end{array}$ & & LOW & HIGH & NEUTRAL & LOW & LOW & HIGH \\
\hline
\end{tabular}

Table 2 - Overview to the cross-case analysis -comparison of case profiles

From Case A, we could hypothesize that a highly robust PM system that provides sufficient information to verify the performance of the contractor compensates for the presence of some opportunistic behavior and concealing of negative outcomes. From Case B, we hypothesize a low degree of goal conflict by itself is not enough to achieve success if accompanied by other agency related causes of failure. 


\subsection{Mechanisms to solving agency issues}

The analysis highlights the important role of mechanisms to solving agency-related issues in five broad areas: contract, understanding, resources, education and delegation. Below we present data and accompanying narrative to each one.

\subsubsection{Contract}

The first area of mechanisms we classify as "contract". Although in each case the contracts had been let, their influence on the project outcomes was still at the forefront as the projects proceeded through execution stage. Central to its influence is the issue of contractual completeness which, as outlined in the literature review, is the degree to which the contract set up at the start of the project is fit for purpose. This entails an assessment of it being fair, equitable to all parties, lacking in any bias, appropriate in its incentives and being a suitable fit to the ongoing project. The case analysis revealed the dynamic nature of contractual completeness and its salience post-contract award. With changes witnessed as the projects moved through the execution phase post-contract award.

To illustrate this mechanism one can compare contractual completeness and its impact on performance in Cases A and D. Case A was successful and Case D was not. Case A utilized an incentivizing contract, with payments to the contractor based on the meeting of key dates and an award fee comprising of two elements. First, an award, worth $50 \%$ of the total, for meeting client Key Performance Indicators (KPIs), such as getting a baseline in place. The client reviewed the KPIs every six months and amended them if required. Second, a negotiated discretionary award, worth the other $50 \%$ of the total. The client program manager talked about the important role of the discretionary award.

"The other $50 \%$ of the award fee is what we call discretionary award fee and that was about demonstrating the right sort of behaviors. The sort of collaborative behaviors that we were expecting to see. The sort of behaviors that drove innovation in safety. (...) So quite a powerful thing, quite an emotive thing because actually there's quite a lot of money on it." (Client program manager, Case A) 
Therefore, the flexible nature of the contract through the changing of the criteria for the award fee ensures the maintaining of contractual completeness throughout the project execution phase. In addition, the client demonstrated a willingness to be pragmatic around the contract and adapt to specific circumstances. For example, the contractor failed to fulfil parts of their contract and were liable for financial penalties. The client needed the contractor to complete their activities in order for a key milestone be met so decided to waive the penalties, which were expressed as the pain part of a gain/pain arrangement, in which the award fee would be the gain.

"So they [contractor] were already projecting a position that was a dispute that was going to put them in to pain. So rather than just resolve that actually what we did was create incentivization for them to get themselves out of pain but hitting some really key milestones, (...) And they hit them. They hit every single one of them. They got all of their incentivization and they got themselves just you know back out of pain. (...) And they kept everything including their completion date on time." (Client program manager/client project manager, Case A)

Case A made changes relating to the contract mid-way through the project to ensure its continuing completeness whilst Case D did not. In Case A the client project representatives recognized in a timely fashion that a reduction in the level of contractual completeness had become a strong inhibiting force to success and, indeed, was likely to lead to failure of the project. The client changed the contract. They waivered contractor penalties and agreed new incentives with the contractors to complete the work to revised timescales. The characteristics of contractual completeness were then present and working for the good of the project. For Case D the contract was at no stage of project execution "complete" and, despite recognizing this, the client did not make any adjustments in the manner of the client to Case A. From the contractor perspective, there was a complete absence of financial incentive in the administration of the contract and indeed a failure to recognize the undertaking of valuable work. The contractor executive director described the situation in stark terms: "well they just want to get money out of us and it's like they just want everything for free." The failure to ensure 
ongoing contractual completeness, with it perceived as unfair, majorly contributed to the relationship breaking down.

\subsubsection{Understanding}

We classify the second area as "understanding". This involves all the various communication activities with the purpose of developing shared understanding as to the project goals, objectives, risks, progress etc. In this sense understanding is broader than just the passive listening, it is a two way active process which requires a message being revealed by one party and then received and made sense of by the other party. What is not surprising is much of the activity took place at the boundaries between the client and contractor organizations. Communication can take various forms and, whilst the frequency and nature of communications between the staff in the client and contractor organizations is crucial, the cases show that other forms of communication, apart from traditional face-to-face meetings, can work perfectly well in some situations. For Case C, which had a high level of success, there was open and honest interorganizational communication mainly via email between the two stakeholders that were at the fulcrum of the client/contractor relationship, namely: the client global lead and the contractor project manager. The open communication channels helped the build-up of trust and hence some of the negative consequences of a typical dysfunctional principal/agent relationship, such as the withholding of information and the practicing of opportunistic behavior was not evident. It is noteworthy that discussions with the clinical outsourcing director revealed that projects of a similar nature, with the same contractor and using the same contractual arrangements, but with a different client global lead and contractor project manager had not gone well.

The respective project managers had not worked together before and the success of the relationship was down to their ability to communicate with each other in the right way and about the right things. The client project manager described the skill of the contractor project manager in this area. 
"So the project manager [contractor] is very good. She is based in [another country to the client project manger's location]. She is a very good communicator. So that always, if there were issues she always escalated them up [to the client project manager]." (Client project manager)

The other case in which client satisfaction was high - Case A - also worked hard on interorganization communication, making sure everyone was aware of "one version of the truth" (Client program manager). By way of contrast the two lower performing projects in terms of client satisfaction (Cases B \& D) had issues with communication, including selective communication of progress, problems etc.

Whilst the importance of building up such inter-organizational shared understanding between parties in different organizations is well recognized, Case B and Case D also illustrates a new finding, the crucial role of intra-organisation understanding. In Case B there was a significant failure in terms of the communication with a key internal stakeholder - the client project manager - by the department responsible for contracts and commercial management, in the initial selection of the contractor. The selection of the contractor by the client to Case B was through competitive tendering, but limited to companies on a preferred supplier list. The client held their details on an online procurement system. Procurement would enter the scope requirements for the project into the system and send out a prequalification questionnaire (PQQ). The client subsequently scores each returned PQQ. The procurement system also allowed the client to obtain current financial information about each bidding contractor. There were four bidders. The client contract manager described how “.... you'd look at the score that the contractor got [on the system] or his financial stability if you like and if it wasn't very high we had other options that we could still use them but we might need a performance guarantee." For the winning bidder, which had the lowest priced tender, "the actual scoring was quite low but it was within the parameters". There was an absence of intra-communication between the contracts department and the project team of the low score. So there was never shared understanding of the potential risk relating to the contractor's ability to deliver. Therefore, when problems started to arise due to the contractor encountering financial difficulties that negatively affected their ability to purchase 
essential products and services from the downstream supply chain, they took the project team by unawares.

A similar failure to build shared understanding both between client and contractor and within their respective organizations was also evident in Case D. The breakdown in trust as the relationship between client and contractor deteriorated - discussed earlier - also fueled negative consequences from an absence of intra-organizational communication within the contractor organization. Specifically the executive director felt deliberately excluded from important communication between the contractor project manager and the client. They described how 'I was taken off all the cc's, I wasn't cc'd into anything". The executive director's explanation for this was that the project manager was doing too much unbillable work aimed at keeping the client happy.

"Everything we sent [the client] wanted to be redesigned and you know to be perfectly honest it was the project manager's fault because if I'd been on that project I would have said [to the Client] "hang on, you're paying this"? We've got eight hours [billable] to do this, we've spent hundreds of hours all potentially, so we should have said no [to the client]." (Executive director - contractor].

Therefore, the lack of intra-organizational communication - and an absence of shared understanding by people within the contractor organization as to the actual progress on the project - led to a lack of trust not only between the client and the contractor but within the contractor organization itself.

\subsubsection{Resources}

The third area of mechanisms we classify as "resources". Resources can take different forms i.e. financial, IT, material but in this context the focus is on having adequacy and constancy of people, in terms of the numbers and their knowledge and experience, to ensure the relationship between the client and the contractor organization(s) run smoothly. The contrasting experiences of Cases A and C illustrate the importance of this factor. For these two cases, the management of resources was a 
mechanism for success. Whereas for Cases B and D, issues around the resourcing of the projects contributed to a lack of success.

Both Cases $\mathrm{A}$ and $\mathrm{C}$ benefitted from an adequate level of resources assigned to the project. They both had individuals with the appropriate PM knowledge and experience attached to the projects. Crucially, in both cases key individuals in both client and contractor organizations remained in their roles throughout project execution. This constancy of resources enabled the maintenance of effective personal relationships.

Conversely, both Cases B and D particularly suffered from some forced and unforced changes in key personnel. On Case B the changes took place within the contractor. Numerous people both left and joined the project as the company involved went through a series of upheavals due to financial difficulties - as explained in the previous section. The client project manager attributed these changes, with the attendant constant cycle of having to start a relationship from scratch with new people, as a major barrier to the development of a fully functional client/contractor relationship. These changes were very much forced on the project and difficult to mitigate. In the words of the client project manager:

"We've got a good team but personalities have come in to it and it has taken a while to develop them because the people on site have changed so much from the contractor's point of view and that's been a difficult part of it."

For Case D a typical response by the client to problems with the project was to request a change to key personnel in the contractor organization. In discussing the point in time at which issues started to become difficult to manage and the relationship with the client to break down, the contractor's executive director observed: "Well it actually dates back a wee bit because we changed our project manager in the New Year $[\ldots .$.$] and also it wasn't a particularly smooth initiation [for the new project$ manager]". So rather than helping address agency-related issues this enforced change of project manager left them worse off due to problems linked to onboarding the new project manager. The 
executive director also highlighted the negative affect of unforced changes in key personnel in the client organization:

"It's interesting that their project manager lasted I think nine months and I know why she left. Because in actual fact one of the project managers who was in that company, [who] I worked with a long time ago - which is why we had the link with the company - and she left and then when I told her the other one was leaving, [she said] yes and I know the reason why. (Executive director - contractor).

The executive director graphically described a non-virtuous cycle, where agency-related issues led to people leaving. This created a lack of resource constancy, which in turn, further fed into the creation of more agency-related issues and the entrenchment of existing ones.

\subsubsection{Education}

We classify the fourth area as "education". Firstly, there was evidence of the positive impact of interorganizational education, which involves going beyond internal training and undertaking additional organizational education initiatives. This is especially the case where the client is seeking certain behaviors from the contractor. For example, in terms of the staff in the contractor organization(s) to supply up-to-date information to enable adequate monitoring of the project to take place. The comments of the client organization of Case A demonstrates the importance attached to inter-organizational education. This involved a two-stage process that starts with internal training of the client's own staff.

“That doesn't just happen easily though. You know so it takes a huge amount of effort to get in to a controlled state, to get in to a baseline that is solid and robust and it has its data integrity is not an easy thing. And it involves quite a lot of investment. We invested in our people so we set up a competency framework. And we aligned that to the Association of PM competencies. So [pre-execution] we said we need this primary competency and this secondary competency. So we had a very structured approach in understanding what we needed from our people and where we didn't have it we went and trained them." (Client program manager) 
The second stage involved engaging with the contractor side to explain the value to the contractor of participating in the PM process i.e. providing accurate and up-to-date information on progress. The client program manager elaborated further on the positive affect of this inter-organizational education.

"You get people believing in why we are asking for information and understanding how it is going to be used. They can get more engaged. If they just think it is another task to add to their list then you just get rubbish. And you know we battled with that and we did a lot of work, [The client project team] did a lot of work educating and actually bringing people along on the journey and saying we need this and this and this." (Client program manager)

The outcome of the initiatives in these two stages was all parties were educated as to the purpose and operation of the PM system and their own role and responsibilities. In addition, it ensured that everybody did the right things, in terms of providing updates i.e. timesheets and percentage completion of deliverables, in both a timely and a consistent way. The timing of the education is also important, with early activity in the execution phase not only helping achieve the beneficial outcome detailed above but also helping to gain buy-in from project staff in terms of fulfilling their required roles as inputters to the PM system. Overall the client program manager believed it led to a "good culture of people providing information because they knew it added value [to the project] whether or not it did to them [personally], it added value to the client and they were keeping their client happy, that means a lot as well."

The experiences of Case D provides a stark contrast. Here the client introduced a new formalized PM monitoring and control system. The client decided that a condition of the project was that it would use the new system. A crucial change between this system and the one that both the client and the contractor previously used was the invoicing done by the contractor would be output based, rather than activity based. So instead of being able to bill the client for $50 \%$ of the cost of visiting sites when half the budgeted for visits had been completed, the client would only be able to charge if half of the planned outputs from the visits had been provided to the client. For example, if the outputs from the visits was 100 case reports written up then the contractor could only invoice for half of the budget when they had written up 50 reports, regardless of how many visits were undertaken. 
This was a major change in the way the contractor had its project work recognized. Unlike Case A, there was no effort by the client to educate the contractor as to the purpose of making such a change and the benefits to the contractor of signing up to the approach. There was no strong sense of buy-in or ownership to the system on the part of staff in the contractor organization and this was a factor that worked against the project achieving successful outcomes. Hence the contractor failed to follow the new system and continued to invoice for work based on the old activity-based system of recognition. This was described by the person in the contractor organization responsible for the invoicing to the client.

“as [our] senior management said it's not an agreed format so we just haven’t spent, I haven’t spent my time on invoicing for it because they, they hadn't agreed to it so, so I haven't really been using it [the new system], (Senior contracts manager).

This failure to adopt the new system by the contractor angered the client and fueled the fire of a dysfunctional client/contractor relationship.

\subsubsection{Delegation}

We classify the fifth and final mechanism as "delegation". Delegation is at the heart of the principal/agent relationship in that the client has to delegate responsibility for the execution of the project to the contractor. Delegation involves the client letting go and trusting the contractor to do the work. For the two projects that were not successful, Cases D and B, a common characteristic was a failure to let go. For Case D, the client was highly knowledgeable in the clinical aspects of the drug being trialed, more so than the contractor. There was a sense that the client was reluctantly outsourcing the work and valued their own clinical skills above non-clinical skills of PM. For the contractor there was a failure on the part of the client to accept that once a client decides to procure an external contractor to undertake a project, they need to trust them to do the job.

“[.... but if people outsource stuff they need to trust the people they outsource to - [there is a] lack of trust - otherwise it won't work and in actual fact the last [project I was involved in] I was involved in a debate whereby one of the things I said was [....] if people were trained in 
outsourcing then maybe they could let go of it [the project management] because it is difficult to do." (Executive director - contractor)

A similar failure to let go was described by staff involved in the other unsuccessful project, Case B. The contractor project manager described how the client was "trying to micro-manage us" and not trusting them to do the job that they were well qualified to do. For example, they described a situation in which they had offered to do some innovative site preparation activities free of charge, which would have enabled earlier undertaking of future project activities. The client declined this offer as in the contractor's opinion it did not "tick one of their KPI boxes". These kinds of frustration on both sides led to problems with trust, concealment of information and negative outcomes, and fed back into the negative cycle of an increasingly dysfunctional relationship.

\section{Discussion and Framework Development}

The study findings illuminate aspects of adverse selection and moral hazard, which are at the heart of agency-related problems, in situations where the client delegates responsibility for project delivery to an external contractor. Agency theory typically applies the phenomenon of adverse selection to the phases of the project undertaken pre-contract award. When information asymmetry exists between the client and the contractor leading to uncertainty as to how the relationship between the two parties will work (Dahlstrom and Ingram, 2003). The findings of our study suggest that the negative consequences of adverse selection are felt beyond contract award. In some failed projects there is a corrosive lingering effect of adverse selection in the reluctance and even resentment on the part of the client in delegating authority to deliver the project to a contractor. This issue is normally regarded as a pre-contract problem. Whilst its source is in this part of the project, there are ripples of negative behaviors that adversely impact on the client/contractor relationship that are still present in project execution.

The study findings confirm current understanding as to the way the key parties deal with moral hazard, which exists post-contract award, which leads to certain project outcomes. Where it is effectively dealt with, for example through the creation of a PM system that enables adequate monitoring of performance, then outcomes can be positive. As was the case with the two successful 
projects. Where it is not effectively dealt with, as with the other two projects, the relationship can play out as per agency theory. Negative agency-related characteristics relating to trust and concealment of information resulting in undesirable outcomes, as described in the literature (Turner and Müller, 2004).

In a similar fashion to the phenomenon of adverse selection and moral hazard the study findings suggest that issues relating to the suitability contract go beyond the design and selection of an appropriate contract at the start of the project. The contract design and selection is clearly crucially important, as recognized in the literature, whether it be outcome-based, behavior-based or an incentivizing hybrid somewhere between the two (Melnyk, et al. 2004; Florical and Lampel, 1998). Business outsourcing literature classifies this notion of fit as contractual completeness (Handley and Benton Jr., 2009). Our study findings suggest that the uncertain environments in projects means that contractual completeness is a dynamic concept and the degree to which it is fit for purpose may be hard to establish at the beginning of a project. As the project progresses and as more information becomes available uncertainty reduces, the ability to assess fit increases. How the client responds to this, for example by making adaptions to the contract design, influences the relationship with the contractor. With the successful projects we analyzed there was a sense that adaptions were countenanced, with the unsuccessful projects there was not this sense.

Our analysis of agency problems relating to the contract shed light on the dichotomy between formal and informal mechanisms described in the literature (Langfield-Smith and Smith, 2003). As one of the five mechanisms to solve agency-related problems we identified by the phenomenological analysis, the way some of the projects used the contract suggest a blurring of the lines between formal and informal mechanisms. Ensuring contractual completeness could be classed as a formal mechanism. But our findings show how informal mechanisms, such as discussing solutions to address problems in the project led to more formal actions like waiving penalties. So examples of formal mechanisms, such as training (Badenfelt, 2010) are complemented with more informal mechanisms aimed at creating cultures of shared values i.e. through ongoing education-related initiatives. Which is another of the five mechanisms we identified. On successful projects the client recognizes the need to deal with both performance risk and relational risk (Zhang and Qian, 2017). This is best done by a combination of formal and informal mechanisms. Hence, our findings suggest that the more informal mechanisms are 
only present if the agency-related issues are low, if trust is present and if the client and contractor had the chance to build a relationship. However, the presence of agency-related problems seems to prohibit the development of informal mechanisms. Our findings also indicate that informal mechanisms are required for formal mechanisms to be put in place and be effective, i.e. informal mechanisms can be viewed as a prerequisite of formal mechanisms. This leads to the suggestion that formal mechanisms to address agency-related problems in a project are only developed if there is a trustful relationship and a common understanding present between the contractor and the client. This relationship then facilitates in the first instance more informal mechanisms to address the problems which are later on converted into formal mechanisms.

We bring together the results of our thematic analysis of the data through the lens of agency theory, which identifies the causes of success or failure and our analysis, which classifies mechanisms linked to the causes in the CURED framework. The framework is shown in figure 1 and takes its name, CURED, from the five mechanisms: Contract, Understanding, Resources, Education and Delegation. As described above, there are a mix of formal and informal activities in each mechanism. Certain mechanisms can also influence the different causes in different degrees - hence the two way arrow between causes and mechanisms in figure 1 - and there are interdependencies between mechanisms and between the agency-related causes of success and failure.

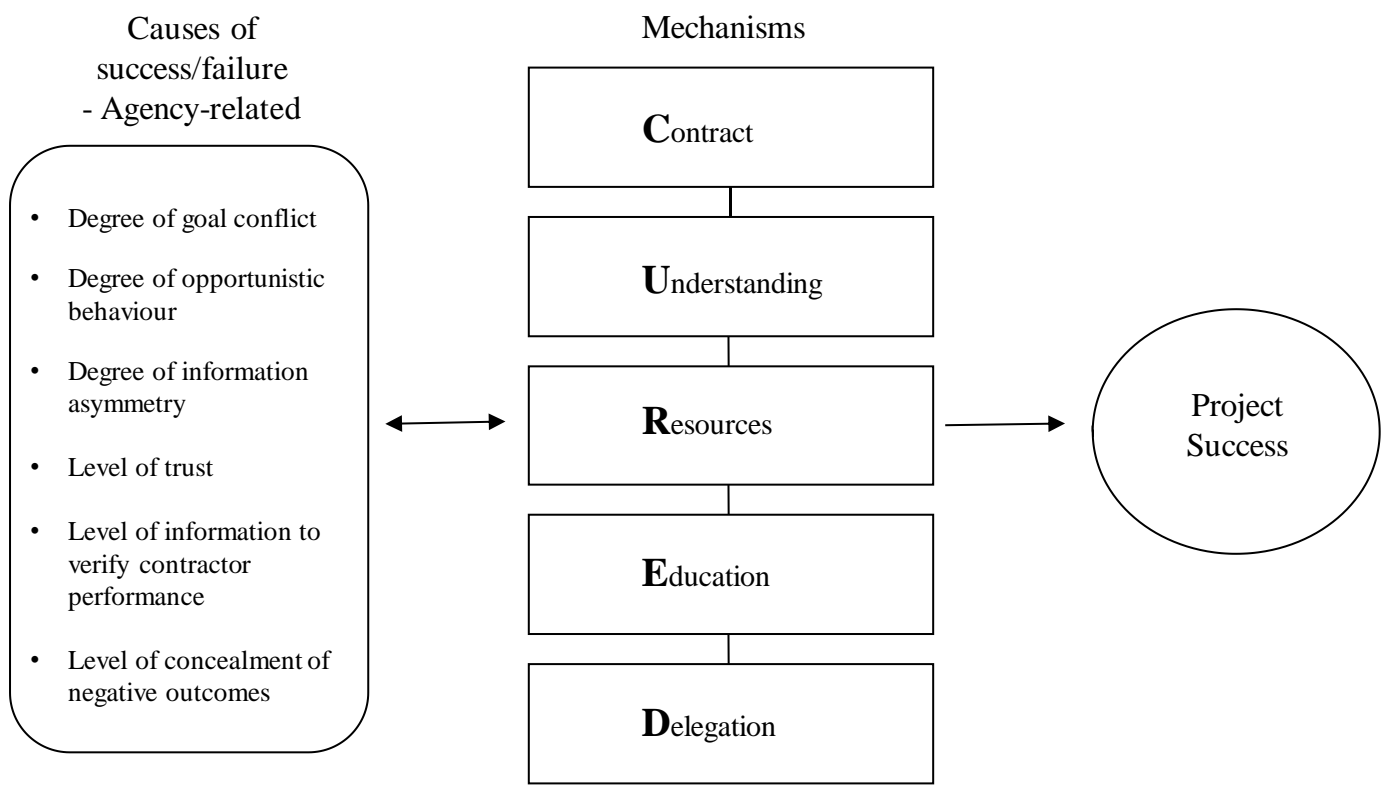

Figure 1 - The CURED framework for resolving agency-related issues to deliver project success 


\section{Conclusions}

In this paper we have explored the role of relationship management in situations where a client sources a project from a contractor that is external to their organization. In doing so we have shed light on the interactions that take place at the micro-level of a project between people involved in PM in the client and the contractor organizations. By using the lens of agency theory we reveal that the ability to address agency-related issues, through these interactions, makes an important contribution to project success. We contribute to knowledge confirming the applicability of agency theory to understanding the complex relational dynamics that exist in certain project environments. In doing so we provide evidence of the importance of not only performance risk but also relational risk in delivering beneficial outcomes to projects. We also extend agency theory by identifying how unique characteristics of the project environment, such as the high levels of uncertainty that exist at the start of the project, require specific mechanisms to deal with agency-related issues. We also differentiate these mechanisms into informal and formal ones, where informal mechanisms can be seen as a pre-requisite for more formal mechanisms.

Our extension of agency theory is reflected in the CURED framework for resolving agencyrelated issues to deliver project success. Our framework provides a meta-level representation of the relationship between 1) mechanisms used by clients and contractors interacting during a project 2) agency-related causes of success and failure and 3) project success. Within the framework we make a contribution to PM knowledge by highlighting the importance of both informal and formal mechanisms. Both types of mechanism are present in the five broad areas we derived from our data: contract, understanding, resources, education and delegation.

Our framework has a practical use for the PM community. The integration of agency theory gives clients a robust lens through which they can view aspects of the relationship between themselves and the contractor. This lens can be trained on prescribing appropriate PM mechanisms at the start of the relationship before project execution commences. It can also help diagnose reasons as to why a relationship is not functioning as hoped for when the execution phase is ongoing - and in these cases facilitate selecting a course of corrective action as part of PM risk management. Traditionally, PM has focused on tools and techniques to manage performance risk to projects. The tools and techniques 
mainly focus on managing discreet events that can impact on performance, such as a contractor not undertaking a specific activity to a defined standard of quality by a certain date. Whilst such tools and techniques are undoubtedly a crucial part of the PM weaponry to deal with risk, our framework provides an additional weapon against another form of risk that can derail a project. The relational risk that is ever-present and embedded deep in projects where the client sources a project from a contractor that is external to their organization.

There are some limitations to our study. Firstly, we have only used the theoretical lens of agency theory to analyze the link between relational-aspects of PM and success. Alternative lenses could be used to both validate the findings and to develop the framework further. Secondly, our framework is derived from data generated from four cases across two industries. Hence any claims to a wider generalizability of the findings need to be made with extreme caution. Additional data needs collecting to test its wider applicability to other industry sectors in which a client sources a project from a contractor external to their organization.

We believe that the framework is a useful starting point in guiding future work into the complex nature of relationship management in situations where the client sources a project from an external organization. Further in depth analysis is needed to identify the ways in which the mechanisms in the broad areas of contract, understanding, resources, education and delegation are operationalized at the micro-level of the project to address the agency-related causes of success and failure. This analysis should explore how the different mechanism interact with each other and with individual agency-related causes. It should also explore the nuances of the relationships between individual mechanisms and specific dimensions of project success i.e. do some mechanisms have a particularly strong positive impact on one dimension, such as meeting time, cost or quality-related criteria? This analysis will be a precursor to future work on validating the framework, where a large-scale survey should focus on testing validity of the constructs for mechanisms and the nature of relationships between the constructs themselves and between the mechanisms, agency-related causes of success/failure and project success.

A second area of future work relates to testing the generalizability of the framework. Future work should validate the framework through a large-scale survey, focusing on its applicability to different types of projects besides construction and clinical trials. The collection of further qualitative 
data, through either additional case studies or in-depth interviews with client and contractor PMs, would be useful to triangulate findings from the surveys and to explore nuances between different project environments.

\section{Acknowledgements}

This research was supported by the Association of Project Management's Planning and Control Special Interest Group. The authors are grateful for their support and for the generous assistance of those who helped us in the collection of data from the cases. We also thank David Davies of ddpc for his helpful suggestions relating to the description of the framework. 


\section{References}

Abrahamson, E. and Park, C. (1994). Concealment of Negative Organizational Outcomes: An Agency Theory Perspective. Academy of Management Journal, 37 (5), 1302-1334.

Akerlof, G.A. (1970). The Market for "lemons": Quality Uncertainty and the Market Mechanism. The Quarterly Journal of Economics, 84 (3), 488-500.

Awuzie, B.O. and McDermott, P. (2015). A conceptual model for evaluating infrastructure-based temporary multi-organisations. Built Environment Project and Asset Management, 5 (1), 103-120.

Badenfelt, U. (2010). I trust you, I trust you not: a longitudinal study of control mechanisms in incentive contracts. Construction Management and Economics, 28 (3), 301-310.

Barratt, M. and Barratt, R. (2011). Exploring internal and external supply chain linkages: Evidence from the field. Journal of Operations Management, 29 (5), 514-528.

Barratt, M., Choi, T.Y. and Li, M. (2011). Qualitative case studies in operations management: Trends, research outcomes, and future research implications. Journal of Operations Management, 29 (4), 29 (4), 329-342.

Bhattacharya, A., Singh, P.J. and Bhakoo, V. (2013). Revisiting the outsourcing debate: two sides of the same story. Production Planning and Control, 24 (4/5), 399-422.

Braun, V. and Clarke, V. (2006). Using thematic analysis in psychology. Qualitative Research in Psychology, 3(2), 77-101.

Byford, M.C. (2017). Moral Hazard in strategic decision making. International Journal of Industrial Organization, 55, 114-136.

Chen, Y. and Anandhi, B. (2009). An Empirical Analysis of Contract Structures in IT Outsourcing. Information Systems Research, 20 (4), 484-506.

Chipulu, M., Ojiako, U., Gardiner , P., Williams, T., Mota, C., Maguire, S., Shou, Y., Stamati , T. and Marshall, A. (2014). Exploring the impact of cultural values on project performance: The effects of cultural values, age and gender on the perceived importance of project success/failure factors. International Journal of Operations \& Production Management, 34 (3), 364 - 389.

Creswell, J.W. (2013). Qualitative Inquiry and Research Design: Choosing among Five Approaches $\left(3^{r d}\right.$ ed.) Sage, Thousand Oaks, CA.

Dahlstrom, R. and Ingram, R. (2003). Social Networks and the adverse selection problem in agency relationships. Journal of Business Research, 56 (9), 767-775.

De Blois, M., Herazo-Cueto, B., Latunova, I. and Lizarralde, G. (2011). Relationships between construction clients and participants of the building industry: Structures and mechanisms of coordination and communication. Architectural Engineering and Design Management, 7, 3-22.

Eisenhardt, K.M. (1989). Agency Theory: An Assessment and Review. Academy of Management Review, 14 (4), 57-74.

Eisenhardt, K.M. (1989a). Building theories from case study research. Academy of Management Review, 14 (4), 532-550. 
Eriksson, P.E. and Lind, H. (2016). Strategies for reducing moral hazard in construction procurement: a conceptual framework. Journal of Self-Governance and Management Economics, (1), 7-33.

Eskerod, P., Huemann, M. and Savage, G. (2015). Project Stakeholder Management - Past and Present. Project Management Journal, 46 (6), 6-14.

Farrell, L. M. (2003). Principal-agency risk in project finance. International Journal of Project Management, 21 (8), 547-561.

Florical, S. and Lampel, J. (1998). Innovative contractual structures for inter-organizational systems. International Journal of Technology Management, 16 (1), 193-206.

Gefen, D., Wyss, S. and Yossi, L (2008). Business Familiarity as Risk Mitigation in Software Development Outsourcing Contracts. MIS Quarterly, 32 (3), 531-542.

Grant, K.P. and Pennypacker, J.S. (2006). Project management maturity: an assessment of project management capabilities among and between selected industries. IEEE Transactions on Engineering Management, 53 (1), $59-68$.

Gopalakrishnan, S., Guilbault, M., Ojha, A.K. (2017) A view from the vendor's side: factors that determine satisfaction. South Asian Journal of Business Studies, 6 (3), 214-228.

Gorla, N. and Somers, T.M. (2014). The impact of IT outsourcing on information systems success. Information and Management, 51 (3), 320-335.

Handley, S.M. and Benton, Jr., W.C. (2009). Unlocking the business outsourcing process model. Journal of Operations Management, 27 (5), 344-361.

Handley, S.M. and Gray, J.V. (2013). Inter-organizational Quality Management: The Use of Contractual Incentives and Monitoring Mechanisms with Outsourced Manufacturing. Production and Operation Management, 22 (6), 1540-1556.

Jensen, M.C. and Meckling, W.H. (1976). Theory of the Firm: Managerial Behavior, Agency Costs and Ownership Structure. Journal of Financial Economics, 3 (4), 305-360.

Jensen, C., Johansson, S., and Löfström, M. (2006). Project relationships-a model for analyzing interactional uncertainty. International Journal of Project Management, 24 (1), 4-12.

Lamminmaki, D. (2011). An examination of factors motivating hotel outsourcing. International Journal of Hospitality Management, 30 (4), 963-973.

Langerfield-Smith, K. and Smith, D. (2003). Management control systems and trust in outsourcing relationships. Management Accounting Research, 14(3), 281-307.

Libertore, M. and Wenhong, L. (2010). Coordination in Consultant-Assisted IS Projects: An Agency Theory Perspective. IEEE Transactions on Engineering Management, 57 (2), 255-269.

Lewin, K. (1951) Field theory in Social Science: Selected theoretical papers (D. Cartwright, ed.). Harpers, Oxford.

Liu, J., Gao, R., Cheah, C. Y. and Luo, J. (2016). Incentive mechanism for inhibiting investors' opportunistic behavior in PPP projects. International Journal of Project Management, 34 (7), 11021111. 
Liu, S., Wang, L. and Huang, W. (2017). Effects of process and outcome controls on business process outsourcing performance: Moderating roles of vendor and client capability risks. European Journal of Operational Research, 260 (3), 1115-1128

Logan, M.S. (2000). Using Agency Theory to Design Successful Outsourcing Relationships. International Journal of Logistics Management, 11 (2), 21-32.

Maaninen-Olsson, E. and Müllern, T. (2009). A contextual understanding of projects - The importance of time and space. Scandinavian Journal of Management, 25 (3), 327-339.

Melnyk, S.A., Stewart, D.M. and Swink, M. (2004). Metrics and performance measurement in operations management: dealing with the metrics maze. Journal of Operations Management, 22 (3), 209-217.

McCarthy, I.P., Silvestre, B.S. and Kietzmann, J.H. (2013). Understanding outsourcing contexts through information asymmetry and capability fit. Production Planning \& Control, 24 (4-5), 277-283.

Melese, Y., Lumbreras, S., Ramos, A., Stikkelman, R. and Herder, P. (2017). Cooperation under uncertainty: Assessing the value of risk sharing and determining the optimal risk-sharing rule for agents with pre-existing business and diverging risk attitudes. International Journal of Project Management, 35 (3), 530-540.

Mir, F.A. and Pinnington, A.H. (2014). Exploring the value of project management: Linking Project Management Performance and Project Success. International Journal of Project Management, 32 (2), 202-217.

Müller, R. and Turner, J. R. (2005). The impact of principal-agent relationship and contract type on communication between project owner and manager. International Journal of Project Management, 23 (5), 398-403.

Obloj, T. and Zemsky, P. (2014). Value creation and value capture under moral hazard: Exploring the micro-foundations of buyer-supplier relationships. Strategic Management Journal, 36 (8), 1146-1163.

PMI (2018). Success in Disruptive Times: Expanding the Value Delivery Landscape to Address the High Cost of Low Performance. Project Management Institute, Newton Square PA.

Ruth, D., Brush, T.H. and Ryu, W. (2015). The use of information technology in the provision of HR compensation services and its effect on outsourcing an centralization. Journal of Purchasing and Supply Management, 21 (1), 25-37.

Shenhar, A.J., Dvir, D., Levy, O. and Maltz, A.C. (2001). Project Success: A Multidimensional Strategic Concept. Long Range Planning, 34 (6), 699-725.

Schneider, B. (1987). The people make the place. Personnel Psychology, 40 (3), 437-453.

Stuart, I., McCutcheon, D., Handfield, R., McLachlin, R. and Samson, D. (2002). Effective case research in operations management: a process perspective. Journal of Operations Management, 20 (5), 419-433.

Taylor, H. (2007). Outsourced IT Projects from the Vendor Perspective: Different Goals, Different Risks. Journal of Global Information Management, 15 (2), 1-27. 
Turner, J.R. and Cochrane, R.A. (1993). Goals-and-methods matrix: coping with projects with ill defined goals and/or methods of achieving them. International Journal of Project Management, 11 (2), 93-102.

Turner, J.R. and Múller, R. (2004). Communication and Co-operation on Projects Between the Project Owner As Principal and the Project Manager as Agent. European Management Journal, 22 (3), $327-$ 336.

Van der Valk, W. and Iwaarden, J.V. (2011). Monitoring in service traids consisting of buyers, subcontractors and end customers. Journal of Purchasing and Supply Management, 17 (3), 198-206.

Yin, R. K. (2013). Case study research: design and methods (5 $\left.5^{\text {th }} e d.\right)$. Sage, Thousand Oaks CA.

Zhang, L. and Qian, Q. (2017). How mediated power affects opportunism in owner-contractor relationships: The role of risk perceptions. International Journal of Project Management, 35 (3), 516529.

Zhang, J.J., Lawrence, B. and Anderson, C. (2015). An agency perspective on service triads: Linking operational and financial performance. Journal of Operations Management, 35, 56-66.

Zheng, L., Lu, W., Chen, K., Chau, K. W. and Niu, Y. (2017). Benefit sharing for BIM implementation: Tackling the moral hazard dilemma in inter-firm cooperation. International Journal of Project Management, 35 (3), 393-405.

Zwikael, O. and Meredith, J. (2018) Who is who in the project zoo? The ten core project roles. International Journal of Operations and Production Management, 38(2), 474-492 


\begin{tabular}{|c|c|c|c|c|}
\hline Case & Project Scope & Organisation Structure & Project Structures, Processes & Selection Criteria \\
\hline $\begin{array}{c}\text { Case A - } \\
\text { construction } \\
\text { project } 1 \text { - } \\
\text { airport } \\
\text { terminal }\end{array}$ & $\begin{array}{l}\text { New purpose built } \\
\text { terminal. Original } \\
\text { estimated cost approx. } \\
\$ 1200 \mathrm{~m} \text {. Part of wider } \\
\text { programme to refurbish } \\
\text { existing airport terminal - } \\
\text { capital cost approx. } \\
\$ 3.2 \mathrm{~b} \text {. Final refurbished } \\
\text { terminal w ould be } \\
\text { approx. } 6 \text { times size of } \\
\text { old terminal, providing } \\
\text { up-to-date facilities for } \\
\text { the air traveller, including } \\
\text { leisure and retail } \\
\text { offerings. }\end{array}$ & $\begin{array}{l}\text { The Principal Contractor was } \\
\text { a joint venture between two } \\
\text { Main Contractor } \\
\text { organisations. For the } \\
\text { provision of the new } \\
\text { terminal the Principal } \\
\text { Contractor acted as a } \\
\text { Complex Building Integrator } \\
\text { (CBI), who was responsible } \\
\text { for managing tier } 2 \\
\text { suppliers. In addition, the } \\
\text { Client employed } 4 \text { Managed } \\
\text { Service Providers (MSP) } \\
\text { who provided a full client } \\
\text { programme management } \\
\text { service. One of these MSPs } \\
\text { was appointed to manage the } \\
\text { project. }\end{array}$ & $\begin{array}{l}\text { Incentivised contracts were let on a competitive basis. The } \\
\text { incentives included rewards for meeting KPIs i.e. finishing work } \\
\text { by certain milestones. There w ere also discretionary payments } \\
\text { made for certain desired behaviours, such as being innovative } \\
\text { and enhancing safety on site. To ensure currency of the KPIs, } \\
\text { they were reviewed and, potentially, changed every } 6 \text { months } \\
\text { throughout the project. A centralised Client Project Management } \\
\text { Office (PMO) was in place to which the MSP provided project } \\
\text { information. This was part of a PM Know ledge Capture (KC) } \\
\text { process that incorporated baseline management, monitoring and } \\
\text { reporting. The KC process was driven by a } 3 \text { stage-month end } \\
\text { reporting cycle involving monitoring against an agreed } \\
\text { performance baseline, preparation of reports and analysis of } \\
\text { variances and a performance review. This enabled performance } \\
\text { to be measured, forecasts made, variances analysed and the } \\
\text { baseline developed and maintained. A set of metrics were put in } \\
\text { place and reported via a Master Report and Project Dashboards, } \\
\text { which were key PM outputs within the overall programme. }\end{array}$ & $\begin{array}{l}\text { Successful. Client } \\
\text { was very satisfied } \\
\text { with the outcome. } \\
\text { Completed on time } \\
\text { and outturn cost } \\
\text { was perceived by } \\
\text { the client to offer a } \\
\text { high level of value } \\
\text { for money. Client } \\
\text { was also happy } \\
\text { with the responses } \\
\text { of the Principal } \\
\text { Contractor and tier } \\
2 \text { suppliers, in } \\
\text { certain instances, } \\
\text { in terms of } \\
\text { meeting key } \\
\text { challenges \& risks. }\end{array}$ \\
\hline $\begin{array}{c}\text { Case B - } \\
\text { construction } \\
\text { project } 2- \\
\text { new water } \\
\text { reservoir }\end{array}$ & $\begin{array}{l}\text { The project involved } \\
\text { construction w ork on two } \\
\text { reservoirs - the } \\
\text { discontinuation of one, } \\
\text { the construction of the } \\
\text { replacement and } \\
\text { associated works, such as } \\
\text { water draining, } \\
\text { landscaping, river re- } \\
\text { instatement etc. The } \\
\text { value of the contract was } \\
\text { approximately } \$ 2.4 \mathrm{~m} \text {, } \\
\text { which was part of a } 5 \text { - } \\
\text { year capital programme } \\
\text { of about } \$ 5.5 \text { billion. }\end{array}$ & $\begin{array}{l}\text { Core project team was PM, } \\
\text { Design Manager, } \\
\text { Construction Manager \& } \\
\text { Project Coordinator (PC). } \\
\text { PC directly reported to PM, } \\
\text { whist the other members of } \\
\text { the core team worked on the } \\
\text { project through a matrix } \\
\text { management structure. } \\
\text { Other team members } \\
\text { included: Project } \\
\text { Controllers, A ccess \& } \\
\text { Acquisitions, Senior Quality } \\
\text { Planners, Estimating } \\
\text { Managers, Contract } \\
\text { Formulation \& Construction } \\
\text { Design Managers. }\end{array}$ & $\begin{array}{l}\text { Contract was aw arded on a fixed price lump sum Design \& } \\
\text { Build. Contractor was selected from list of approved suppliers } \\
\text { and through a two stage process involving a pre-qualification } \\
\text { from a tender list of four contractors. The contractor selected } \\
\text { which w as local to the area provided the cheapest tender. A } \\
\text { range of KPIs were in place including areas like customer } \\
\text { service, people, Health \& Safety \& sustainability, with points } \\
\text { awarded against each. A Standard Operating Model (SOM) for } \\
\text { project delivery was in place. This included Needs, Concept, } \\
\text { Definition, Implementation and Handover/Closedown phases. A } \\
\text { Client Project Delivery System (PDS) included a project } \\
\text { repository. This held information relating to standardized life } \\
\text { cycle processes, templates and guidance notes. The PDS sought } \\
\text { to provide a consistency of approach and the application of best } \\
\text { practices to all projects. The PM system included tracking against } \\
\text { programme, contract and deliverables; shared risk register, } \\
\text { regular formal meetings and formal reporting up to the PDS. }\end{array}$ & $\begin{array}{l}\text { Unsuccessful. The } \\
\text { client was } \\
\text { unhappy with } \\
\text { certain aspects of } \\
\text { its management, } \\
\text { including a lack of } \\
\text { communication } \\
\text { from the } \\
\text { Contractor to the } \\
\text { Client, and with } \\
\text { performance } \\
\text { against some of } \\
\text { the KPIs. }\end{array}$ \\
\hline
\end{tabular}




\begin{tabular}{|c|c|c|c|c|}
\hline $\begin{array}{l}\text { Case C - } \\
\text { clinical trial } \\
\text { project } 1- \\
\text { investigatio } \\
\text { nal product } \\
\text { for the } \\
\text { treatment of } \\
\text { lung cancer }\end{array}$ & $\begin{array}{l}\text { The clinical trial stage of } \\
\text { the drug development } \\
\text { process involving a } \\
\text { proxiuct for potentially } \\
\text { treating lung cancer. The } \\
\text { selection process and the } \\
\text { implementation of the } \\
\text { project, with its } \\
\text { operational governance, } \\
\text { took about } 18 \text { months. }\end{array}$ & $\begin{array}{l}\text { Outsoureed the project to a } \\
\text { Clinical Research } \\
\text { Organisation (CRO). A } \\
\text { Master Services Agreement } \\
\text { (MSA) was in place with } \\
\text { penalty and bonus clauses, } \\
\text { with built-in discounts at the } \\
\text { front-end of the project. The } \\
\text { client attempted to retain a } \\
\text { degree of competitiveness by } \\
\text { getting both contractors to } \\
\text { bid on all let contracts. }\end{array}$ & $\begin{array}{l}\text { There were no core metrics in the MSA. Neither was there a } \\
\text { formal process for evaluating if contracts and projects were } \\
\text { successful or not. After the contract was awarded the Client } \\
\text { generated a PM responsibilities log that listed all of the activities } \\
\text { and who is responsible for what. A Questions \& Answers log } \\
\text { was also created to formally capture the management of issues. } \\
\text { A schedule showing critical and non-critical activities was also } \\
\text { created, and there were well established processes between the } \\
\text { companies for remote communication, including a monthly status } \\
\text { report. With these processes and documents acting as a support a } \\
\text { fairly light touch PM approach was adopted by the respective } \\
\text { client and contractor organisations in terms of centralised control } \\
\text { on how the project was managed through the exeeution stage; } \\
\text { with a degree of discretion being given to the client PM in terms } \\
\text { of how they engaged on a day-to-day basis with the contractor. }\end{array}$ & $\begin{array}{l}\text { Successful. The } \\
\text { client was very } \\
\text { satisfied with all } \\
\text { aspects of its } \\
\text { management and } \\
\text { its outcomes. }\end{array}$ \\
\hline $\begin{array}{l}\text { Case D - } \\
\text { clinical trial } \\
\text { project } 2 \text { - } \\
\text { investigatio } \\
\text { nal product } \\
\text { for the } \\
\text { treatment of } \\
\text { haemophilia }\end{array}$ & $\begin{array}{l}\text { The trial of a drug for the } \\
\text { treatment of a rare form } \\
\text { of haemophilia. The } \\
\text { project scope included } \\
\text { the identification and } \\
\text { monitoring of suitable } \\
\text { patients, which in such } \\
\text { trials is often not } \\
\text { straightforward - and } \\
\text { hence requires careful } \\
\text { PM. }\end{array}$ & $\begin{array}{l}\text { Within the client was the } \\
\text { Head of Clinical Operations } \\
\text { - responsible for the project; } \\
\text { the Clinical Project Leader - } \\
\text { who had the day-to-dlay } \\
\text { oversight of the project; and } \\
\text { the Clinical Study Manager - } \\
\text { responsible for the clinical } \\
\text { aspects of the project. For } \\
\text { the Contractor, key people } \\
\text { were: the Project Manager, } \\
\text { finance officers responsible } \\
\text { for invoicing and for revenue } \\
\text { analysis/forecasting, and an } \\
\text { Executive Director dealing } \\
\text { with contractual issues. }\end{array}$ & $\begin{array}{l}\text { Contract was awarded after a competitive tendering process and } \\
\text { was let on a fixed-price basis. Awarded to the lowest bidder, a } \\
\text { company which the client bad not worked with before. Gantt } \\
\text { chart was proxiuced showing schedule of work. At the start the } \\
\text { client decided to adopt a new PMS to monitor progress and to } \\
\text { pay the Contractor for work undertaken. High level deliverables } \\
\text { were identified and baseline costs related to the activities linked } \\
\text { to the deliverables allocated. Metrics were generated on a } \\
\text { monthly basis. Payment was only made when a deliverable was } \\
\text { classed as a certain percentage complete i.e. } 50 \% \text {. This was } \\
\text { different to the approach the contractor usually worked with, } \\
\text { which involved payment for activities undertaken. This was the } \\
\text { first time that the client had used the new PMS and the contractor } \\
\text { also had no experience of using it. Additional project reporting } \\
\text { was done against the activities in the schedule, through a series of } \\
\text { spreadshects that are shared between client and contractor. }\end{array}$ & $\begin{array}{l}\text { Unsuccessful. An } \\
\text { eventual } \\
\text { breakdown in the } \\
\text { relationship } \\
\text { between the two } \\
\text { parties to the } \\
\text { project mid-way } \\
\text { through the } \\
\text { project, led to the } \\
\text { cancellation of the } \\
\text { contract by the } \\
\text { client with the } \\
\text { clinical trial not } \\
\text { completed with } \\
\text { this contractor. }\end{array}$ \\
\hline
\end{tabular}

APPENDIX 1: Details of the case study projects 